\title{
Population structure of giant clams (Tridacnidae) in Aceh Besar District Waters
}

\author{
M Rizki Fazillah'², Chitra Octavina ${ }^{1}$, Muhammad Agustiar ${ }^{2}$, Muhammad Akhyar $^{2}$ \\ ${ }^{1}$ Department of Marine Science, Faculty of Marine Affairs and Fisheries, Syiah Kuala University, Banda Aceh, 23111, \\ Indonesia. \\ ${ }^{2}$ Ocean Diving Club, Faculty of Marine Affairs and Fisheries, Syiah Kuala University, Banda Aceh, 23111, Indonesia. \\ *Corresponding author: chitraoctavina@unsyiah.ac.id
}

ARTICLE INFO
Keywords:
Aceh Besar; Density; Distribution
pattem; Giant dams; Population
structure; Tridacnidae
How to cite:
Faziillah, M. R., Octavina,
C., Agustiar, M., \& Akhyar,
M. (2020). Population
structure of giant clams
(Tridacnidae) in Aceh Besar
District Waters. Tomini
Journal of Aquatic Science,
1(2), 73-80.

\begin{abstract}
Giant clams have an essential ecological role in the coral reef ecosystem. Given the decreasing number of giant clams in nature, the status of giant clams as protected animals, and there is still little information about giant clams, data or information is needed to make policies regarding giant clam conservation management. This study aimed to determine the population structure of giant clams (Tridacnidae) in the coral reef area of Aceh Besar District. The research was conducted in May 2018, located in Aceh Besar Regency waters with six observation stations. Observation of giant clams is carried out using a visual census technique with the belt transect method. The observations showed that the giant clams found in Aceh Besar waters consisted of 2 species, namely Tridacna maxima and Tridacna crocea. Overall stations, the individual density of giant clams is 0.041 ind. $\mathrm{m}^{-2}$. The diversity index of giant clams shows a value ranging from $0-0.97$, classified in the low diversity category. The similarity index value of giant clams is classified into the stressed to stable similarity category with values ranging from $0-0.97$. The dominance index value of giant clams is classified in the medium to high dominance category with values ranging from 0.52 to 1 . The distribution pattern of the two giant clam species found in the waters of Aceh Besar District has a uniform distribution pattern with values ranging from $0.20-0.29$. The overall population structure of Tridacnidae is in unstable condition.
\end{abstract}

\section{INTRODUCTION}

Giant clams are one of the types of bivalves (Tridacnidae) most often found in coral ecosystem waters. Geographically, giant clams have a limited distribution in the tropical Indo-Pacific region, from the red sea to the Pacific Islands of Tuamotu (Harahap et al., 2018). Giant clams live in association with coral reefs by drilling and then submerging themselves in the substrate. They have a bright pigment in the mantle that comes from their association with zooxanthellae algae (Hernawan, 2008; Niartiningsih, 2012). Eight types of giant clams live in Indonesia from 12 species that live in the world, namely: Tridacna gigas, $T$. derasa, $T$. maxima, $T$. squamosa, 
T. crocea, T. noae, Hippopus hippopus, and H. porcellanus (Hernawan, 2012; Borsa et al., 2015; Sadili et al., 2015).

Giant clams have an essential ecological role in coral reef ecosystems (Neo et al., 2017). This biota acts as a natural biofilter capable of filtering dissolved ammonia and nitrates in seawater for nitrogen requirements in the zooxanthellae growth process (Braley, 2009). Its complex shell structure becomes a habitat for fish to lay eggs, care for, and take shelter (Neo et al., 2015). Not only play a role in ecological processes, but giant clams are also known to have important economic value (Richter et al., 2008). The trade of giant clams in the Asia Pacific market utilizes all parts of the giant clam organ (Calumpong, 1992). In addition to being used as a source of food, their shells are used as decoration, jewelry (Pada et al., 2013), the ceramic industry, handicrafts (Wabnnitz et al., 2003), and juvenile giant clams to decorate marine aquariums (Wabnnitz et al., 2003; Nijman et al., 2015), the public believes even the giant clam meat to have powerful medicinal properties.

Triandiza et al. (2019) stated that overexploitation causes the survival rate and giant clams population to decrease. Besides, the destruction of coral reefs as a habitat for giant clams has caused a decline in these animal populations (Lesmana \& Wahyudin, 2016), which has led to the extinction of various giant species of giant clams in nature (Yusuf et al., 2009). The government has issued regulations regarding the designation of giant clams as protected animals because their population in nature has greatly decreased. Based on the Decree of the Minister of Forestry No. 12 Kpts-II/1987 and Government Regulation No.7/1999, it was determined that all types of giant clams that live in Indonesia are protected animals. Even giant clams have been included in the CITES appendix II list (Griffiths \& Klumpp, 1996) and the UICN Red List of Threatened Species (IUCN, 2007).

Aceh Besar District has an area of $290,350.73 \mathrm{Ha}$. Most of the area is on the mainland, and a small part is in the archipelago. Geographically, Aceh Besar District is located at 503'1,2"5045'9,007" North Latitude and 95055'43,6"-94059'50.13" East Longitude (BPS Aceh Besar District, 2020). One of Aceh Besar district biodiversity is a coral reef ecosystem that is a habitat for giant clams. Several studies related to giant clams in the waters of Aceh Besar District have been carried out and reported (Bahri et al., 2015; Ayuniara et al., 2018; Fadli et al., 2019). However, research that specifically examines the population structure of giant clams has never been studied in Aceh, especially Aceh Besar. With the decreasing number of giant clams in nature, giant clams as protected animals, and the lack of information on giant clams in Aceh, data or information is needed to make policies regarding giant clam conservation management.

\section{MATERIAL AND METHODS}

This research was conducted in May 2018, which is located in the waters of Aceh Besar District. There are six observation stations: Station 1 Blang Ulam, Station 2 Benteng Inong Balee, Station 3 Pulau Tuan, Station 4 Lamteng, Station 5 Meulingge, and Station 6 Lhok Udeung. Geographically, the research location is located at the coordinate point (see Figure 1).

Determination of observation locations, Observation stations are determined by purposive sampling by looking at the overall representation of the research area based on the availability of coral reef ecosystems. Station was determined by walking along the coast while visually observing the location of coral reefs as a habitat for giant clams. Determination of station points is marked by taking the coordinates using GPS (Global Positioning System) 


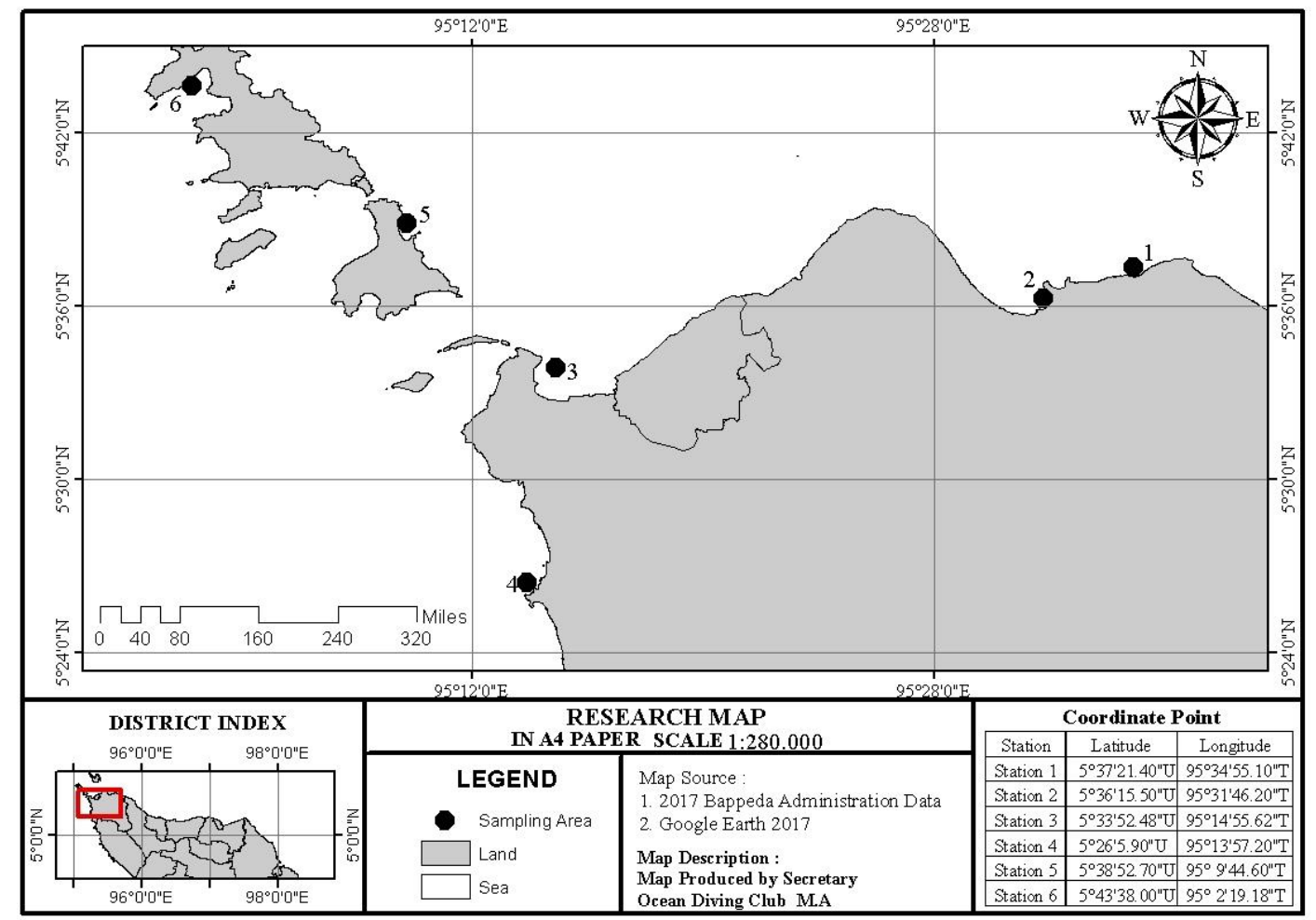

Figure 1. Study site. The black dot $(\bullet)$ indicates the location of Tridacnidae sampling at Aceh Besar Waters, Aceh, Indonesia.

Data collection. The tools and materials used in this study are the SCUBA tool, roll meter $(100 \mathrm{~m})$, underwater camera, underwater writing instrument, and giant shell identification book, which refers to Copland and Lucas (1988). Observation of giant clams was carried out using a visual census technique with the belt transect method (English et al., 1994). The data recording for giant clams is carried out at a shallow depth $(0-6 \mathrm{~m})$, using a $100 \mathrm{~m}$ line transect with a distance of $2.5 \mathrm{~m}$ to the left and $2.5 \mathrm{~m}$ to the right.

Data analysis, The data analysis in this study includes density index, diversity index, similarity index, dominance index, and distribution pattern.

The density index for giant clams is calculated based on Brower and Zar (1977) using the following formula:

$$
\mathrm{D}=\mathrm{Ni} / \mathrm{A}
$$

Information:

D : Density index (ind. $\mathrm{m}^{-2}$ )

$\mathrm{Ni} \quad$ : Number of individuals i (ind.)

A : Area $\left(\mathrm{m}^{2}\right)$

Based on Planes et al. (1993) criteria for the density of giant clams, namely: 0 ind. $\mathrm{m}^{-2}=$ no density; $<1$ ind. $\mathrm{m}^{-2}=$ low density; 2 ind. $\mathrm{m}^{-2}=$ low to medium density; $3-4$ ind. $\mathrm{m}^{-2}=$ medium density; 5 ind. $\mathrm{m}^{-2}=$ medium to high density; $>5$ ind. $\mathrm{m}^{-2}=$ high density

The five diversity index is calculated based on the Shannon-Weiner formula (Odum, 1993):

$$
H^{\prime}=-\Sigma \text { pi Log2 pi }
$$

Information: 
$\mathrm{H}^{\prime} \quad$ : Shannon-Weiner diversity index

pi : Proportion of the number of individuals ( $\mathrm{ni} / \mathrm{N}$ )

ni : Number of individuals of type $\mathrm{i}$

$\mathrm{N} \quad$ : The total number of all individuals

Log2 pi: $3.321 \times$ Log pi

Diversity index refers to Krebs (1989); $\mathrm{H}^{\prime}<1$ belongs to the category of low diversity and unstable community; $1<\mathrm{H}^{\prime} \leq 3$ belongs to the category of moderate diversity and communities with moderate stability; $\mathrm{H}^{\prime}>3$ belongs to the category of high diversity and stable community.

The similarity index of giant clams is calculated based on the Krebs (1989) formula:

$$
E=H^{\prime} /(H \max -\log S)
$$

Information:

E : Similarity index

$\mathrm{H}^{\prime} \quad$ : Diversity index

Hmax : 3.321928 Log S

$\mathrm{S} \quad$ : Number of species found

The similarity index value ranges from $0-1$. If the similarity index is close to the value 0 , then the individual distribution of each species is not uniform, and the ecosystem tends to be dominated by species caused by the instability of environmental factors and population. If the similarity index approaches a value of 1 , then the ecosystem is in relatively the same condition.

The dominance index of giant clams is calculated based on the Odum (1993) formula:

$$
\mathrm{C}=\Sigma(\mathrm{ni} / \mathrm{N})^{2}
$$

Information:

C : Dominance Index

ni : The number of individuals of the ith type

$\mathrm{N} \quad$ : The total number of individuals

The domination index value can be classified as follows: if the value is $0<\mathrm{C} \leq 0.5$, then the dominance is low; $0.5<\mathrm{C} \leq 0.75$, then the dominance is classified as moderate; and a value of $0.75<\mathrm{C} 1.00$ is classified as high dominance (Krebs, 1989).

The distribution pattern was calculated based on Brower and Zar (1977). The value of Id $<1$ means that the individual is uniform, while for the value Id $>1$, it means that the individual is grouped.

$$
I_{d}=\left(N i^{2}-N\right) /(N(N-1))
$$

Information :

Id : Spread Index

$\mathrm{Ni} \quad$ : Number of individuals (ind.)

$\mathrm{N} \quad$ : Total individuals (ind.)

\section{RESULTS AND DISCUSSION}

Density. The results showed that the giant clams found in the waters of Aceh Besar consisted of 2 species, namely Tridacna maxima and Tridacna crocea, with the same genus and families, 
namely the Tridacnidae and Tridacna families. The two giant clam species were not found at all observation stations, but some stations only found one of the two species. There were 56 species of Tridacna crocea found; this species was not found in the Blang Ulam (ST1) location. While the Tridacna maxima species were found more than Tridacna crocea, which was 64 individuals. The species Tridacna crocea was not found at Pulau Tuan (ST3) and Meulingge (ST6). In all, the total number of giant clams found was 123 individuals. The appearance of giant clam species for each station is presented in Table 1 below:

Table 1. The appearance of giant clam species at each station in Aceh Besar District waters

\begin{tabular}{lccccccccc}
\hline \multirow{1}{*}{ Family } & Genus & Species & ST1 & ST2 & ST3 & ST4 & ST5 & ST6 & Ind. \\
\hline Tridacnidae & Tridacna & Tridacna crocea & - & + & + & + & + & + & 56 \\
& & Tridacna maxima & + & + & - & + & + & - & 67 \\
\hline Total & & & & & & & & & 123
\end{tabular}

Information: +: Yes -: No

The highest density of giant clams found at the observation location was at Station 5 , with a density value of 0.084 ind. $\mathrm{m}^{-2}$, while the lowest density of giant clams was at Station 1 with a value of 0.014 ind. $\mathrm{m}^{-2}$. The high and low density of giant clams is closely related to the water conditions suitable for giant clams to adapt and survive. Padilah et al. (2015) stated that the substrate is an important parameter for giant clams to survive. The suitable substrate for giant clams is usually in areas of coral reefs, sand, and rock fragments. Overall, the density of individual giant clams in this study was 0.041 ind. $\mathrm{m}^{-2}$, which means that in an area of one hectare, there are 410 individual giant clams.

Referring to the criterion for the density of giant clams, if the density value is less than one, the giant clam population is in low condition (Planes et al., 1993). In this case, the density of giant clams in Aceh Besar waters is in a low category. The density value of giant clams is high compared to the research conducted by Marzuki et al. (2013) in Berhala Island waters and Hasni et al. (2017) in Wowosunggu waters, South Konawe Regency, where the density values range from 0.02 to 0.06 ind. $\mathrm{m}^{-2}$. This difference in value is due to the varying time of the study and the coverage area. Besides, it is suspected that the hunting of giant clams is higher than the waters of Aceh Besar District in these waters. The density of giant clams in Aceh Besar waters is shown in Figure 2.

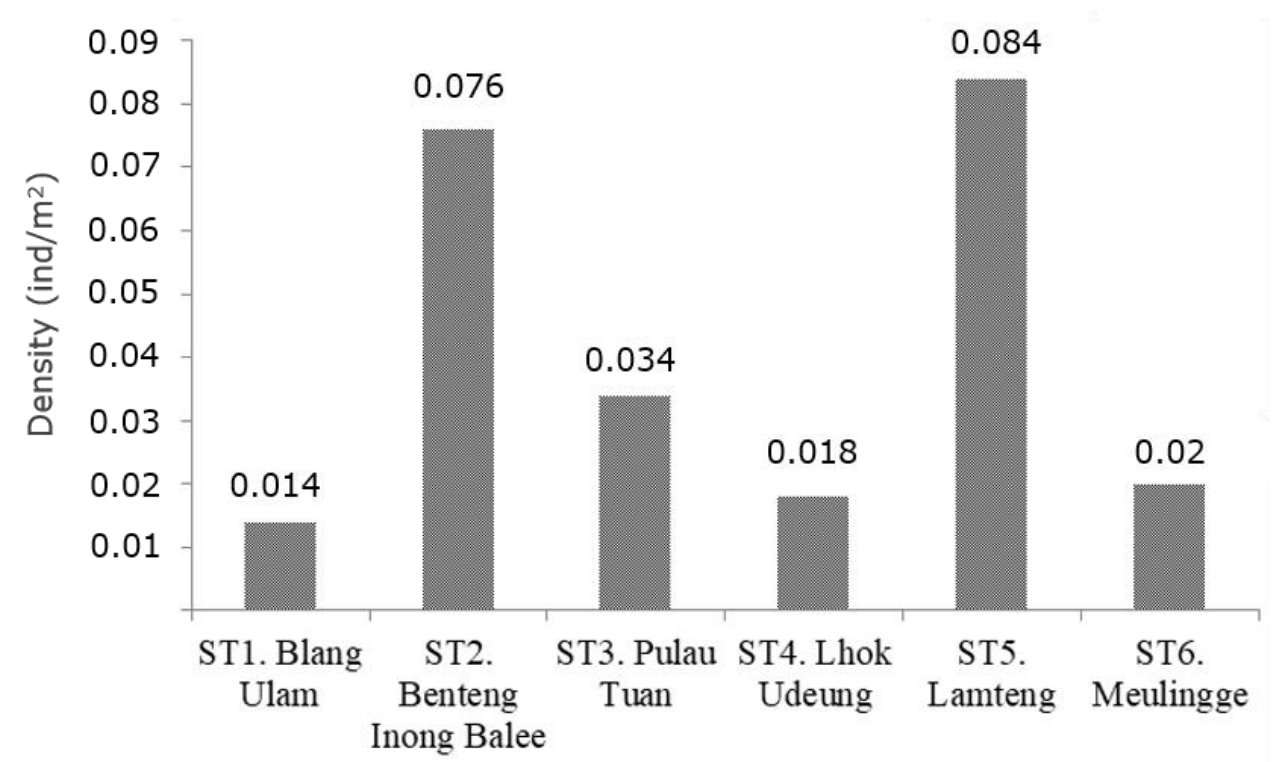

Figure 2. Density of giant clams (ind. $\mathrm{m}^{-2}$ ) in the waters of Aceh Besar District. 
Diversity. Overall, the diversity index of giant clams shows a value $<1$, classified in the low diversity category. Even at the location of Blang Ulam (ST1), Pulau Tuan (ST3), and Meulingge (ST6), the diversity index value of giant clams is 0.00 . There are not many variations of giant clam species found in Aceh Besar waters; this means that the giant clam community is unstable. Rasidi et al. (2004) stated that abiotic factors could directly or indirectly affect the presence, density, and distribution of species. The substrate is one of the abiotic factors that significantly affect the richness, distribution, and diversity index of marine organisms, especially Tridacnidae (Nybakken, 1992; Sastrawijaya, 1991). The diversity index value of giant clams in the waters of Aceh Besar Regency is presented in Table 2.

Similarity. The similarity index value was divided into two categories of conditions. The observation locations of Benteng Inong Balee (ST2), Lhok Udeung (ST4), and Lamteng (ST5) are classified as stable conditions of species similarity. It means that the ecosystem at that location is in relatively the same condition. On the other hand, the observation locations of Blang Ulam (1), Pulau Tuan (ST3), and Meulingge (ST6) are classified as stressed species similarity conditions. The more evenly the distribution of individuals between species in a giant clam community will increase the ecosystem balance (Odum, 1993). Besides, the presence of predators is thought to be a factor affecting the survival of giant clams (Arbi, 2010). The biggest predator of the giant clams, in this case, is humans. Due to the high frequency of hunting certain species with a higher selling value, the diversity of giant clams is reduced and dominated by less desirable species. It can be seen from the results of research that only found one giant clam species in locations with stressed species similarity categories. The diversity index value of giant clams in the waters of Aceh Besar Regency is presented in Table 2.

Dominance. The results of the calculation of the dominance index value show that there is high dominance at the three observation locations, namely Blang Ulam (ST1), Pulau Tuan (ST3), and Meulingge (ST6), with the dominance index value of 1 . In contrast, the other observation locations are classified in the moderate dominance category. The low diversity and similarity index values indicate a high dominance of a species over other species (Odum, 1993). Besides, the instability of environmental and population factors can cause the distribution of individuals for each species not to be uniform, so that the ecosystem tends to have species dominance (Krebs, 1989). The diversity index value of giant clams in the waters of Aceh Besar Regency is presented in Table 2.

Table 2. Structure of the giant clam community in the waters of Aceh Besar District

\begin{tabular}{lcccccc}
\hline \multicolumn{1}{c}{ Stations } & $\begin{array}{c}\text { Diversity } \\
\left(\mathrm{H}^{\prime}\right)\end{array}$ & Category & Similarity (E) & Category & Dominance (C) & Category \\
\hline ST1. Blang Ulam & 0 & Low & 0 & Stress & 1 & High \\
ST2. Benteng Tua & 0.79 & Low & 0.79 & Stable & 0.64 & Moderate \\
ST3. Pulau Tuan & 0 & Low & 0 & Stress & 1 & High \\
ST4. Lhok Udeung & 0.92 & Low & 0.92 & Stable & 0.56 & Moderate \\
ST5. Lamteng & 0.97 & Low & 0.97 & Stable & 0.52 & Moderate \\
ST6. Meulingge & 0 & Low & 0 & Stress & 1 & High \\
\hline
\end{tabular}

Distribution pattern. The two giant clam species found in the waters of Aceh Besar have a regular distribution pattern with values ranging from $0.20-0.29$. Uniform distribution can occur where competition between individuals is very high, and some positive antagonists encourage the same division of space. Physical and chemical factors in the waters, which are almost the same in habitat and the availability of food for the organisms that live in it, determine the distribution pattern of the organisms (Suin, 2002). The distribution pattern of giant clams in Aceh Besar waters is presented in Table 3. 
Table 3. The distribution pattern of giant clams in Aceh Besar waters

\begin{tabular}{lcc}
\hline Species & Distribution index $\left(\mathrm{I}_{\mathrm{d}}\right)$ & Distribution Pattern \\
\hline Tridacna crocea & 0.29 & Uniform \\
Tridacna maxima & 0.20 & Uniform \\
\hline
\end{tabular}

\section{CONCLUSION}

The observations showed that the giant clams found in Aceh Besar waters consisted of 2 species, namely Tridacna maxima and Tridacna crocea. Overall stations, the individual density of giant clams is 0.041 ind. $\mathrm{m}^{-2}$. The diversity index of giant clams shows a value $<1$, which is classified in the low diversity category. The similarity and dominance index values were divided into two condition categories. Benteng Inong Balee, Lhok Udeung, and Lamteng Stations are classified in a stable condition of species similarity and moderate species dominance, while Blang Ulam Station, Pulau Tuan, and Meulingge are classified in conditions of suppressed species similarity and high species dominance. The distribution pattern of the two giant clam species found in Aceh Besar waters has an uniform distribution pattern.

\section{REFERENCES}

Arbi, U. Y. (2010). Density and habitat conditions of clam shells (Cardiidae: Tridacnidae) in several locations in North Sulawesi waters. Bawal, 3(2), 139-148. http://dx.doi.org/10.15578/bawal.3.2.2010.139-148

Ayuniara., Muntahariah dan Nursalbiah. (2018). Benthos diversity index in the waters of Deudap Pulo Nasi Beach, Aceh Besar District. Prosiding Seminar Nasional Biotik. https://jurnal.ar-raniry.ac.id/index.php/PBiotik/article/view/4280

BPS Aceh Besar District. (2020). Aceh Besar District in 2020 figures. BPS Kabupaten Aceh Besar.https://acehbesarkab.bps.go.id/publication/2020/04/27/f62cdf3c52a326a908d9092 7/kabupaten-aceh-besar-dalam-angka-2020.html.

Bahri, S., Rudi, E., \& Dewiyanti, I. (2015). Condition of coral reefs and macro invertebrates in Ujong Pancu Waters, Peukan Bada District, Aceh Besar [Indonesian]. DEPIK: Jurnal IlmuIlmu Perairan, Pesisir, dan Perikanan, 4(1), 1-7. https://doi.org/10.13170/depik.1.1.2278

Borsa, P., Fauvelot, C., Tiavouane, J., Grulois, D., Wabnitz, C., Abdon Naguit, M. R., \& Andréfouët, S. (2015). Distribution of Noah's giant clam, Tridacna noae. Marine Biodiversity, 45, 339-344. https://doi.org/10.1007/s12526-014-0265-9

Fadli, N., Muchlisin, Z. A., Soraya, I., Dewiyanti, I., Purnawan, S., El-Rahimi, S. A., Sofyan, H., Affan, M., \& Siti-Azizah, M. N. (2019). The diversity of marine macroinvertebrates in Aceh Besar waters, Aceh, Indonesia. IOP Conference Series: Earth and Environmental Science. 348, 1-6. https://doi.org/10.1088/1755-1315/348/1/012076

Griffiths, C. L., \& Klumpp, D. W. (1996). Relationships between size, mantle area and zooxanthellae numbers in five species of giant clam (Tridacnidae). Marine Ecology Progress Series, 137, 139-147. https://doi.org/10.3354/meps137139

Harahap, S. A., Yanuar, Y., \& Ilham, Y. (2018). Diversity and abundance of giant clams in Anambas Islands, Indonesia. E3S Web of Conferences, 47, 1-9. https://doi.org/10.1051/e3sconf/20184703005

Hasni, Sadarun, B and Ira. (2017). Diversity and density of clam species in the waters of Wowosunggu Island, South Konawe Regency. Sapa Laut, 2(4): 113-118.

Hernawan, U. E. (2008). Symbiosis between the Giant Clams (Bivalvia; Tridacninae) and Zooxanthellae (Dinoflagellatae). Biodiversitas, https://doi.org/10.13057/biodiv/d090113

Hernawan, U. E. (2012). Taxonomy of Indonesian giant clams (Cardiidae, Tridacninae). Biodiversitas, 13(3), 118-123. https://doi.org/10.13057/biodiv/d130303

Krebs, C. J. 1989. Ecological Methodology. New York. NY Harper and Row Publishers Inc. 654p. Lesmana, D., \& Wahyudin, Y. (2016). Sustainable Use of Kima. Jurnal Mina Sains, 2(1), 1-14. 
https://doi.org/10.30997/jms.v2i1.423

Marzuki, Ismail, D. G., Sadarun., Baru P and Ratna, D. (2013). Condition of coral reefs and abundance of clams in Indo Island waters. Jurnal Mina Laut Indonesia. 01(01):61-72.

Neo, M. L., Eckman, W., Vicentuan, K., Teo, S. L. M., \& Todd, P. A. (2015). The ecological significance of giant clams in coral reef ecosystems. Biological Conservation, 181, 111123. https://doi.org/10.1016/j.biocon.2014.11.004

Neo, M. L., Wabnitz, C. C. C., Braley, R. D., Heslinga, G. A., Fauvelot, C., Van Wynsberge, S., Andréfouët, S., Waters, C., Shau-Hwai Tan, A., Gomez, E. D., Costello, M. J., \& Todd, P. A. (2017). Giant clams (Bivalvia: Cardiidae: Tridacninae): A comprehensive update of species and their distribution, current threats and conservation status. Oceanography and Marine Biology: An Annual Review. https://doi.org/10.1201/b21944

Nijman, V., Spaan, D., \& Nekaris, K. A. I. (2015). Large-scale trade in legally protected marine mollusc shells from Java and Bali, Indonesia. PLOS ONE, 10(12), e1040593. https://doi.org/10.1371/journal.pone.0140593

Odum, E.P. (1993). Fundamentals of Ecology. (Translators: Samingan T. \& Srigandono B.) Gadjah Mada University Press. Yogyakarta [Indonesian].

Pada, D. N., Boneka, F. B., \& Mamangkey, G. F. (2013). Identification and ecological aspects of tridacninae shells in the waters around Venu Island, Kaimana Regency, West Papua Province [Indonesian]. Jurnal Ilmiah Platax, 1(2), 45-53. https://doi.org/10.35800/jip.1.2.2013.1244

Padilah, M, Arief, P dan Andi, Z. (2015). The distribution pattern of clams in the waters of the bay in Malang village, Gunung Kijang sub-district, Bintan Regency, Riau Islands.

Planes, S., C. Chauvet, J. Baldwin, J. Bonvallot, Y. Fontaine-Vernaudon, C. Gabrie, P. Holthus, C. Payri, \& R. Galzin. (1993). Impact of tourism related fishing on Tridacna maxima (Mollusca: Bivalvia) stocks in Bora-Bora Lagoon (French Polynesia). Attol Research Bulletin, 385. National Museum of Natural History, Smithsonian Institution, Washington D. C. https://agris.fao.org/agris-search/search.do?recordID=AV20120137793

Rasidi, S., Basukriadi, A. \& Ischak, T. M. (2004). Animal Ecology. Pusat Penerbitan Universitas Terbuka. Jakarta. 13(9): 28.

Richter, C., Roa-Quiaoit, H., Jantzen, C., Al-Zibdah, M., \& Kochzius, M. (2008). Collapse of a New Living Species of Giant Clam in the Red Sea. Current Biology, 18(17), 1349-1354. https://doi.org/10.1016/j.cub.2008.07.060

Sastrawijaya, A.T. (1991). Environmental Pollution. PT. Rineka Cipta, Jakarta. 83-87.

Suin, N. M. 2002. Measurement of biotic environmental factors. Jurusan Biologi FMIPA. Universitas Andalas. Padang.

Triandiza, T., Zamani, N. P., Madduppa, H., \& Hernawan, U. E. (2019). Distribution and abundance of the giant clams (Cardiidae: Bivalvia) on Kei islands, Maluku, Indonesia. Biodiversitas, 20(3), 884-892. https://doi.org/10.13057/biodiv/d200337

Yusuf, C., \& Hartati, R. (2012). Abundance of Tridacna (Family Tridacnidae) at Seribu Islands and Manado Waters, Indonesia. Ilmu Kelautan - Indonesian Journal of Marine Sciences, 14(3), 150-154. https://doi.org/10.14710/ik.ijms.14.3.150-154 